\title{
Motivation Towards Career Choice of Brazilian Freshman Students in a Fifteen-Year Period
}

\author{
Maria do Carmo Matias Freire, Ph.D.; Lidia Moraes Ribeiro Jordao, D.D.S.; \\ Naiara de Paula Ferreira, D.D.S.; Maria de Fatima Nunes, Ph.D.; \\ Maria Goretti Queiroz, Ph.D.; Claudio Rodrigues Leles, Ph.D.
}

\begin{abstract}
Examining dental students' profiles and perspectives contributes to discussions concerning dental education and practice. This study aimed, first, to investigate Brazilian dental students' reasons for pursuing dentistry as an occupation and, secondly, to consider the professional expectations of freshman students at a Brazilian public university over a fifteen-year period. A crosssectional study was performed using data from a self-administered questionnaire to all first-year students enrolled in the $1993-95$ and 2006-08 periods at the Federal University of Goias, Brazil (n=376). A total of 296 students responded (response rate=78.7 percent). Frequency analysis and chi-square tests were used to compare frequencies between the two time periods. Job conception was cited as the primary reason for pursuing dentistry, and the students considered oral health promotion and oral disease prevention as the primary purposes of dentistry. Most students intended to serve both high and low socioeconomic populations and both private and public practices after graduation. The majority cited an interest in specializing in clinical fields, orthodontics being the most frequent option. Significant trends included a greater interest in health promotion and public services and specializing in aesthetic dentistry and implantology in the 2006-08 period. This study revealed significant differences in the freshman students' motivations and professional perspectives over time. Personal views and concepts about profession are major influencing factors for choosing dentistry as a career.
\end{abstract}

Dr. Freire is Associate Professor, School of Dentistry, Federal University of Goias, Goiania, Brazil; Dr. Jordao is a dental surgeon, Belfast, United Kingdom; Dr. Ferreira is an M.Sc. student, School of Dentistry, State University of Campinas, Piracicaba, Brazil; Dr. Nunes is Adjunct Professor, School of Dentistry, Federal University of Goias, Goiania, Brazil; Dr. Queiroz is Associate Professor, School of Dentistry, Federal University of Goias, Goiania, Brazil; and Dr. Leles is Associate Professor, School of Dentistry, Federal University of Goias, Goiania, Brazil. Direct correspondence and requests for reprints to Dr. Maria Freire, School of Dentistry, Federal University of Goias, Praça Universitaria, Goiania, Goias, 74605-220, Brazil; mcmfreire@yahoo.com.br.

Keywords: dental education, students, dental, career choice, professional practice, Brazil

Submitted for publication 3/5/10; accepted 7/14/10

I nvestigating the views and professional perspectives of health students contributes to a better understanding of how they direct their studies during the academic period, plan their career, guide their interpersonal relationships, and determine the role they play in society. In a broader sense, such investigations may also be useful to subsidize the planning and evaluation processes in undergraduate health education and health care services, as these issues may influence institutional curriculum, teaching processes, and the profiles of future professionals.

Several studies have been performed on the socioeconomic profile, career choice, and professional perspective of dental students worldwide. In general, results indicate that career choice is usually motivated by vocation and status and that most students are more concerned with technical matters and professional status than with their role in society. ${ }^{1-18}$
Because these findings may change throughout the years, it is interesting to monitor the situation by comparing data collected at different times. Only two studies reporting trends have been published. ${ }^{17,18}$ In South Africa, changes were observed in the gender and race proportions of dental students over time, but their reasons for choosing dentistry remained the same..$^{17}$ In Denmark, ${ }^{18}$ there were no changes in gender distribution and a greater female proportion prevailed. Furthermore, we found that students put a greater emphasis on social status as a reason for choosing to pursue dentistry.

In Brazil, the country with the highest number of dentists in the world (19 percent), there are currently 197 dental schools. ${ }^{19}$ However, despite the significant reduction of caries prevalence in children observed over the last decades, the oral health status of adults and access to health care for the general 
population is poor. ${ }^{20}$ Over the past few years, the Ministries of Education and of Health put into place certain strategies aimed at developing a more appropriate personnel profile for the National Health System and for the needs of the population..$^{21,22}$ Therefore, insight into students' perceptions and expectations about the future profession are relevant to the implementation of the new policies.

Studies about Brazilian dental students' profiles and perceptions concerning their professional career have shown consistent results. $1,2,6,7,9,11,12,14,23,24$ At the dental school of the Federal University of Goias, a public university located in the midwest of Brazil, data on these matters have been collected since the beginning of the 1990s. Two previous studies found that most of the students intended to work in private clinics and to become specialists after graduating. ${ }^{9}{ }^{912}$ Considering recent changes in the profession, we have hypothesized that freshman students' perspectives might also have changed over the years. The aim of the present study was, first, to investigate Brazilian students' reasons for choosing dentistry as a career and, secondly, to examine the professional expectations of Brazilian freshman dental students from one public university in a fifteen-year period.

Age Gender ( ) Female ( ) Male

Why did you choose a dental course?

In your opinion, what is the main purpose of dentistry?

Where do you intend to work after graduating?
( ) In my own practice. Why?
( ) In the public service. Why?
( ) Both. Why?
( ) Do not know
( ) Other(s)

What kind of clientele do you intend to have?

( ) Low-income population

( ) Population with higher incomes

( ) Do not know

Do you intend to specialize in a field after graduating?
( ) $\mathrm{No}$
( ) Do not know yet
( ) Yes. What field?

Figure 1. Questionnaire for freshman dental students regarding their motivation towards career choice and professional perspective

\section{Methods}

The study sample included all first-year students from the Federal University of Goias, Brazil, in the years 1993, 1994, 1995, 2006, 2007, and 2008 $(n=376)$. Participation was voluntary and anonymous. The study sample excluded foreign students and those who had initiated the course previously in other universities.

Brazilian candidates for university must pass an admission test covering all the disciplines of high school education. Public universities commonly use this exam to select candidates out of an extremely competitive applicant pool due to the high proportion of applicants per place. School admission depends on the student's rank in the admission test, considering a limited number of places. ${ }^{25}$ Unlike many other countries, students are not required to work in public service after graduating. The dental course at the Federal University of Goias is a five-year, full-time course.

The research protocol was approved by the Ethics Committee of the Federal University of Goias. Informed consent was obtained from all 2007 and 2008 freshmen who agreed to participate. The head of the dental school provided signed permission for the use of data collected in the previous years.

A cross-sectional study was carried out using data collected in the period 1993-2008. The research instrument was a self-applied questionnaire adapted from previous studies, ${ }^{23,24}$ which students answered in class at the beginning of their first year of the course. A cover letter explaining the aims, procedures, benefits, and risks of the research and a consent form were distributed alongside the questionnaire.

The questionnaire consisted of nine closed and open questions (Figure 1). They included demographic data (age and gender) and career choicerelated data. Questions on career choice included the reasons for choosing dentistry, purpose of dentistry, type of service intended after graduating, reasons for choosing this type of service, socioeconomic level of the intended customers, intention to become specialists, and preferred specialty field.

For open questions (reasons for choosing dentistry, purpose of dentistry, reasons for intended type of service, and preferred specialty), all answers were read and classified into categories, using content analysis technique. The Statistical Package for Social Sciences (SPSS for Windows version 16.0) was used for statistic tests. To evaluate differences in the stu- 
dents' responses over the fifteen years, a chi-square test was performed to compare proportions between two periods: $1993-95$ and 2006-08. When $\mathrm{p}<0.05$, it was considered significant. Adjusted standardized residuals were used to determine which categories (cells) were major contributors to rejection of the null hypothesis. When the absolute value of the residual was greater than 2.00 , it was concluded that the category had a major influence on a significant chi-square test statistic.

\section{Results}

Response rate was 78.7 percent. Of the 296 respondents, 141 were from the period 1993-95 and 155 were from 2006-08. The age of students ranged from sixteen to twenty-seven (mean=19; $\mathrm{SD}=2$ ). Of the total, 192 (64.9 percent) were women, 102 (34.5 percent) were men, and two did not respond to the gender question. The percentage of women increased from 62.4 percent in 1993-95 to 67.1 percent in 2006-08.

From the total sample, the students' primary reason for choosing dentistry was "job conception" (72.4 percent), as shown in Table 1. This included answers related to self-perceived vocation, interest in biological sciences, professional fulfillment, and admiration for dentists. Comparisons between the two periods analyzed showed differences in the frequencies of all response categories, and three of the five categories were significant. Furthermore, the number of students who chose "personal fulfillment" decreased, whereas the number of those who chose "influence of others" as the reason for pursuing dentistry increased over the period $(\mathrm{p}<0.001)$. Although only 6.6 percent of the total sample chose dentistry because they wished to "contribute to people's health," there was a significant rise in the number of students in this category $(\mathrm{p}=0.005)$.
When asked about the main purpose of dentistry, most of the students said it was "oral health promotion and oral disease prevention" (67 percent) and "disease treatment" (30.9 percent) (Table 2). Only 8.9 percent mentioned "serving the community" as the main purpose. There was a significant drop in the analyzed period regarding "oral health promotion and oral disease prevention" $(\mathrm{p}=0.014)$, whereas there was a significant rise in "general health promotion and disease prevention" $(\mathrm{p}=0.015)$ and aesthetics $(\mathrm{p}=0.013)$.

The majority of the students had already decided on the type of practice they intended to have after graduating (76.7 percent) (Table 3). The most frequent option was to work in both private clinics and public services (41.2 percent). A few students (2.7 percent) intended to work exclusively in public services, and this option was chosen only in the later years. The intention to work in both sectors rose, whereas the intention to work only in private clinics dropped from 1993-95 to 2006-08 ( $\mathrm{p}<0.001)$.

More than half of the students did not know yet what socioeconomic groups they intended to work with (55.7 percent) (Table 3). Approximately 20 percent of the sample intended to work with both high- and low-income populations, and the same proportion chose to work exclusively with the highincome population. Only 4.5 percent intended to work exclusively with the low-income population. Intention to work with both and with high-income populations increased over time $(p<0.001)$. The number of students who were not sure about the type of practice and socioeconomic groups they favored also decreased $(\mathrm{p}=0.001)$.

Most of the students revealed the intention to become specialists $(\mathrm{N}=215 ; 72.6$ percent $)$, whereas 26.7 percent $(\mathrm{N}=79)$ had not yet decided, one did not intend to become a specialist, and one did not respond to this question. The percentage of those who intended to specialize increased from 65.2

Table 1. Reasons for choosing dentistry as a career among Brazilian dental students, 1993-95 and $2006-08$

\begin{tabular}{|c|c|c|c|c|}
\hline Reason & $\begin{array}{l}1993-95 \\
(N=136)\end{array}$ & $\begin{array}{c}2006-08 \\
(N=154)\end{array}$ & $\begin{array}{c}\text { Total } \\
(\mathrm{N}=290)\end{array}$ & Chi-square test \\
\hline Job conception & $93(68.4 \%)$ & $117(76.0 \%)$ & $210(72.4 \%)$ & $2.08(p=0.149)$ \\
\hline Personal fulfillment & $38(27.9 \%)$ & $11(7.1 \%)$ & $49(16.9 \%)$ & $22.25(p<0.001)$ \\
\hline Financial motives & $27(19.9 \%)$ & $21(13.6 \%)$ & $48(16.6 \%)$ & $2.02(p=0.155)$ \\
\hline Influence of others & $8(5.9 \%)$ & $37(24.0 \%)$ & $45(15.5 \%)$ & $18.14(p<0.001)$ \\
\hline Contribution to people's health & $3(2.2 \%)$ & $16(10.4 \%)$ & $19(6.6 \%)$ & $7.90(p=0.005)$ \\
\hline
\end{tabular}

Note: Respondents could choose more than one reason. For this question there were six nonrespondents. 
Table 2. Purpose of dentistry according to Brazilian dental students, 1993-95 and 2006-08

\begin{tabular}{lcccc} 
Purpose & $\begin{array}{c}1993-95 \\
(\mathrm{~N}=136)\end{array}$ & $\begin{array}{c}2006-08 \\
(\mathrm{~N}=155)\end{array}$ & $\begin{array}{c}\text { Total } \\
(\mathrm{N}=291)\end{array}$ & Chi-square test \\
\hline Oral health promotion and oral disease prevention & $101(74.3 \%)$ & $94(60.6 \%)$ & $195(67.0 \%)$ & $6.08(\mathrm{p}=0.014)$ \\
Disease treatment & $46(33.8 \%)$ & $44(28.4 \%)$ & $90(30.9 \%)$ & $1.00(\mathrm{p}=0.317)$ \\
Health promotion and disease prevention & $10(7.4 \%)$ & $26(16.8 \%)$ & $36(12.4 \%)$ & $5.93(\mathrm{p}=0.015)$ \\
To serve the community & $9(6.6 \%)$ & $17(11.0 \%)$ & $26(8.9 \%)$ & $1.69(\mathrm{p}=0.194)$ \\
Aesthetics & $4(2.9 \%)$ & $16(10.3 \%)$ & $20(6.9 \%)$ & $6.17(\mathrm{p}=0.013)$
\end{tabular}

Note: Respondents could choose more than one purpose. For this question there were five nonrespondents.

Table 3. Type of practice and socioeconomic groups favored by Brazilian dental students, 1993-95 and $2006-08$

\begin{tabular}{|c|c|c|c|c|}
\hline \multirow[b]{2}{*}{ Type of practice } & 1993-95 & 2006-08 & Total & $\begin{array}{c}\text { Adjusted } \\
\text { standardized residuals }\end{array}$ \\
\hline & $\mathrm{N}=141$ & $N=155$ & $N=296$ & $*$ \\
\hline Private practice & $53(37.5 \%)$ & $42(27.0 \%)$ & $95(32.0 \%)$ & 1.9/-1.9 \\
\hline Public services & 0 & $8(5.1 \%)$ & $8(2.7 \%)$ & $-2.7 / 2.7^{* *}$ \\
\hline Both & $44(31.2 \%)$ & $78(50.3 \%)$ & $122(41.2 \%)$ & $-3.3 / 3.0^{* *}$ \\
\hline Others (teaching) & 0 & $2(1.3 \%)$ & $2(0.6 \%)$ & $-1.4 / 1.4$ \\
\hline Did not know & $44(31.2 \%)$ & $25(16.1 \%)$ & $69(23.3 \%)$ & $3.1 /-3.1^{* *}$ \\
\hline Socioeconomic group ${ }^{+}$ & $N=137$ & $N=152$ & $\mathrm{~N}=289$ & $* * *$ \\
\hline Low-income population & $6(4.4 \%)$ & $7(4.6 \%)$ & $13(4.5 \%)$ & $0.0 / 0.1$ \\
\hline High-income population & $18(13.1 \%)$ & $38(25.0 \%)$ & $56(19.4 \%)$ & $-2.5 / 2.5^{* *}$ \\
\hline Both & $20(14.6 \%)$ & $39(25.7 \%)$ & $59(20.4 \%)$ & $-2.3 / 2.3^{* *}$ \\
\hline Do not know & $93(67.9 \%)$ & $68(44.7 \%)$ & $161(55.7 \%)$ & $4.0 /-4.0^{* *}$ \\
\hline \multicolumn{5}{|c|}{$\begin{array}{l}{ }^{+} \text {For this question there were seven nonrespondents. } \\
{ }^{*} \text { Chi-square test }=25.38(p<0.001) \\
{ }^{* *} \text { Categories with major influence on the significant chi-square test statistic. } \\
{ }^{* * *} \text { Chi-square test }=16.49(p=0.001)\end{array}$} \\
\hline
\end{tabular}

percent in 1993-95 to 79.4 percent in 2006-08. The students indicated a total of nine of the nineteen existing specialties in Brazil (Table 4), all in clinical and diagnostic fields. Orthodontics was the most frequent (23.0 percent). Choices of orthodontics, implantology, and restorative and aesthetic dentistry largely contributed to the chi-square results $(\mathrm{p}<0.001)$ when the two periods were compared. The option for orthodontics decreased, whereas implantology and aesthetics increased over time.

\section{Discussion}

We detected significant differences in the participants' responses between the two time periods. Although the design of the study did not always allow us to look into possible influencing factors for trends over the fifteen-year period, some contextual factors related to the profession and dental education in Brazil are relevant to this discussion. The results regarding gender, for example, reflect the increasing number of female dentists in the country, and a recent report on the Brazilian dental surgeons profile and trends indicates that these female dentists have become the majority since the end of the 1990s. ${ }^{19}$ Two studies also reported this trend in other countries. ${ }^{17,18}$

Our findings concerning the reasons for choosing dentistry confirmed those found in other studies in India, ${ }^{26}$ Jordan, ${ }^{27}$ and Brazil. ${ }^{9,23}$ In general, students chose a dental career due to the concept they had of dentistry as a profession.

There was a significant rise in the number of students who chose dentistry due to the influence of others, and similar reasons have also been reported by other studies. A study performed with American 
Table 4. Intended specialties among Brazilian dental students, 1993-95 and 2006-08

\begin{tabular}{|c|c|c|c|c|}
\hline Specialty fields & $\begin{array}{l}1993-95 \\
(\mathrm{~N}=141)\end{array}$ & $\begin{array}{l}2006-08 \\
(N=155)\end{array}$ & $\begin{array}{c}\text { Total } \\
(\mathrm{N}=296)\end{array}$ & $\begin{array}{c}\text { Adjusted } \\
\text { standardized residuals }\end{array}$ \\
\hline Orthodontics & $47(33.3 \%)$ & $21(13.5 \%)$ & $68(23.0 \%)$ & $4.0 /-4.0^{*}$ \\
\hline Implantology & $2(1.4 \%)$ & $19(12.3 \%)$ & $21(7.1 \%)$ & $-3.6 / 3.6^{*}$ \\
\hline Surgery & $5(3.5 \%)$ & $9(5.8 \%)$ & $14(4.7 \%)$ & $-0.9 / 0.9$ \\
\hline Restorative and Aesthetic Dentistry & 0 & $14(9.0 \%)$ & $14(4.7 \%)$ & $-3.7 / 3.7^{*}$ \\
\hline Periodontology & $5(3.5 \%)$ & $5(3.2 \%)$ & $10(3.4 \%)$ & $0.2 /-0.2$ \\
\hline Odontopediatrics & $4(2.8 \%)$ & $4(2.6 \%)$ & $8(2.7 \%)$ & $0.1 /-0.1$ \\
\hline Prosthodontics & $3(2.1 \%)$ & $3(1.9 \%)$ & $6(2.0 \%)$ & $0.1 /-0.1$ \\
\hline Endodontics & $2(1.4 \%)$ & $2(1.3 \%)$ & $4(1.4 \%)$ & $0.1 / 0.0$ \\
\hline Radiology & 0 & $1(0.6 \%)$ & $1(0.3 \%)$ & $-1.0 / 1.0$ \\
\hline $\begin{array}{l}\text { Did not know/did not inform/did not } \\
\text { intend }\end{array}$ & $73(51.8 \%)$ & $77(49.7 \%)$ & $150(50.7 \%)$ & $0.4 /-0.4$ \\
\hline \multicolumn{5}{|c|}{$\begin{array}{l}\text { Chi-square test }=39.38(\mathrm{p}<0.001) \\
{ }^{*} \text { Categories with major influence on the significant chi-square test statistic. }\end{array}$} \\
\hline
\end{tabular}

and Swedish students showed a strong parental influence on career choice, and a previous Brazilian study reported that nearly half of the sample had dentists in the family, suggesting that they may have influenced the students. ${ }^{1,28}$ In another American study, a slight majority identified their family dentist as having the greatest influence on their decision. ${ }^{29}$

Although there was a significant increase in the number of students who were motivated by the possibility of "serving the community" over the analyzed period, only a few students indicated this reason, contrasting with studies performed in developed countries. ${ }^{5,19,30}$ Reinforcing this view, only a small percentage of the participants indicated "contribution to people's health" as their main reason for choosing dentistry as a career and intended to work with lowincome populations. This is interesting to consider as there has been an increasing number of dental students from low socioeconomic backgrounds in Brazil over the last few years. ${ }^{19}$

However, the high number of students who considered "oral health promotion and oral disease prevention" as the main purpose of dentistry and the increasing emphasis placed on general health are positive aspects of the study. These findings follow the trend towards integral health care in the public services. ${ }^{31}$ On the other hand, a greater emphasis has been placed on aesthetics as the purpose of dentistry over time, which confirms the current attention given to cosmetic dentistry in Brazil.

For 68.0 percent of the students, private service alone is not the preferred option, and this percentage was lower than that reported in another Brazilian $\operatorname{study}^{6}(86.4$ percent). Only 2.7 percent expected to work exclusively in public services, and this option appeared only in the more recent period (2006-08). Similar results were found in the United Kingdom, ${ }^{32}$ where labor shortage and accessibility problems in the National Health Service dental services are a cause for concern.

The high preference for both public and private sectors may be due to factors related to the Brazilian public services, which usually pay low salaries but still provide job security and may also allow workers to dedicate themselves to private practice. The Brazilian report on dental surgeons found that two-thirds of them work on their own and that the workplaces in the public health sector have grown in the last few years. ${ }^{19}$ In fact, with continuing poverty among the majority of the population ${ }^{33}$ who thus have limited access to private practice, many professionals have preferred to work exclusively in public services. On the other hand, none of the respondents in our study intended to specialize in public health.

The high percentage of freshman students who intended to specialize as well as their early specialty field definition may be a result of the increasing number of specialization courses in Brazil over the last few years. ${ }^{19,34}$ Orthodontics as the preferred specialty among the respondents parallels findings in previous studies in Brazil, ${ }^{9,11}$ the United Kingdom, ${ }^{32}$ the United States ${ }^{29}$ and South Africa. ${ }^{35}$ Comparisons between studies conducted in different countries should, however, be made with care since there may be differences in education, family, and social and political systems that may influence students' 
views of dentistry as well as their motivations and expectations.

The choice of orthodontics has been seen to decrease over time in our study, whereas implantology and aesthetics increased. Regarding the variable purposes of dentistry, aesthetics appears in the more recent period analyzed, and this may be due to reasons such as the decline in dental caries among children ${ }^{20}$ and the increase in the population's life expectancy in the last decades, ${ }^{36}$ as well as the growing investment in dental industries and the general emphasis on physical appearance in Brazil. It is worth commenting that, although reported by the students as either isolated from or as part of restorative dentistry, aesthetics itself is not a specialization registered by the Dentistry National Council. ${ }^{19}$

The findings of our study must also be interpreted in light of recent changes in Brazilian dental education. Guidelines for Health Degrees were established in Brazil in 2001, aiming at general and specific development of professionals based on health promotion, prevention, recovery, and rehabilitation..$^{22}$ It also includes the usual competencies for a more adequate profile within national and international quality standards. As a consequence, some Brazilian universities have been changing their curricula, as is the case with the Federal University of Goias, where this study was conducted. More studies are therefore needed to evaluate whether current changes will be fully adequate to develop professionals with the appropriate knowledge, skills, and values required to perform their role in society.

This study was carried out in only one Brazilian dental school, and the students surveyed are therefore not representative of all Brazilian dental students. Despite this limitation, the study has made a first attempt to investigate important aspects of health education in Brazil and Latin America over an extended period. Further investigations are needed to increase our knowledge about the factors that influence students' concepts and perspectives, as these factors may vary between countries and cultures.

\section{REFERENCES}

1. Almeida JRE, Almeida RCA, Cabral OEJ. A escolha da profissão odontológica: motivação consciente. Odontol Moderna 1984;11(11):21-6.

2. Arbenz GO, Abramowicz M, Abramowicz M, Silva M. Motivos conscientes na escolha da profissão odontológica. Rev Odontol Univ Sao Paulo 1973;11(1):101-10.

3. Brand AA, Chikte UM. Choosing dentistry as a career. Part II: the meaning of motives. J Dent Assoc S Afr 1992; 47:509-12.
4. Brand AA, Chikte UM. Student attitudes to dentistry in South African dental schools. J Dent Assoc S Afr 1997; 52:713-20.

5. Brand AA, Chikte UM, Thomas CJ. Choosing dentistry as a career: a profile of entering students (1992) to the University of Sydney, Australia. Aust Dent J 1996;41(3): 198-205.

6. Brustolin J, Brustolin J, Toassi RFC, Kuhnen M. Perfil do acadêmico de Odontologia da Universidade do Planalto Catarinense-Lages-SC, Brasil. Rev ABENO 2006; 6(1):66-9.

7. Carvalho DR, Carvalho ACP, Sampaio H. Motivações e expectativas para o curso e para o exercício da Odontologia. Rev Assoc Paul Cir Dent 1997;51(4):345-9.

8. Crossley ML, Mubarik A. A comparative investigation of dental and medical students' motivation towards career choice. Br Dent J 2002;193:471-3.

9. Freire MC, Souza CS, Pereira HR. O Perfil do acadêmico de Odontologia da Universidade Federal de Goiás. Divulg Saude Debate 1995;10:15-20.

10. Karibe H, Kawakami T, Suzuki A, Warita S, Ogata K, Aoyagi K, et al. Career choice and attitudes towards dental education amongst dental students in Japan and Sweden. Eur J Dent Educ 2009;13:80-6.

11. Meinicke BL, Tomacheski DF, Fadel CB, Baldani MH. Perspectivas do exercício profissional entre calouros e formandos do curso de Odontologia da Universidade Estadual de Ponta Grossa-Paraná. Odontol Soc 2002;4(2):18-23.

12. Queiroz MG. Óbvio ou obscuro: estudo das representações sociais dos alunos dos cursos de Medicina e Odontologia da UFG acerca de suas profissões. Cad Educ 1998;6: 45-60.

13. Wittemann JK, Currier GF. Motives to enter the dental profession: students, practitioners, faculty. J Dent Educ 1976;40(5):265-8.

14. Pacca S, Corrêa L, Motta M. Auto-imagem do cirurgiãodentista: um estudo baseado em desenhos de alunos de graduação. Rev ABENO 2003;3(1):82-5.

15. Skelly AM, Fleming GJ. Perceptions of a dental career among successful applicants for dentistry compared with those of fifth-year dental students. Prim Dent Care 2002;9(2):41-6.

16. Chattopadhyay A, Chatterjee M. Career aspirations of dental students in a dental college in Calcutta, India. Indian J Dent Res 1991;2:10-2.

17. Brand AA, Chikte UM. Choosing dentistry as a career. Part I: a comparison of student motives. J Dent Assoc S Afr 1992;47(11):469-73.

18. Vigild M, Schwarz E. Characteristics and study motivation of Danish dental students in a longitudinal perspective. Eur J Dent Educ 2001;5(3):127-33.

19. Morita MC, Haddad AE, Araújo ME. Perfil atual e tendências do cirurgião-dentista brasileiro. Maringá: Dent Press Int., 2010.

20. Cury JA, Tenuta LMA, Ribeiro CCC, Paes Leme AF. The importance of fluoride dentifrices to the current dental caries prevalence in Brazil. Braz Dent J [online] 2004;15(3):167-74 .

21. Programa Nacional de Reorientação da Formação Profissional em Saúde-Pró-Saúde. Brasília, DF: Ministério da Saúde, Secretaria de Gestão do Trabalho e da Educação na Saúde, 2005. 
22. Diretrizes Curriculares Nacionais dos Cursos de Graduação em Odontologia. Brasília, DF: Ministério da Educação, Parecer CNE/CES nº 1300/01, 2001.

23. Slavutzky SMB, Abbeg C, Gross RF, Rosa MAC. Mercado de trabalho: perfil do acadêmico de odontologia da Universidade Federal do Rio Grande do Sul. Rev Fac Odontol P Alegre 2002;43(2):3-6.

24. Lengruber AA, Santos ACB, Marques A, Sasso CT, Ferreira CCP, Ferreira EM, et al. O perfil do estudante de Odontologia. Odontol Capixaba 1989;18:27-31.

25. Silva ET, Nunes MF, Queiroz MG, Leles CR. Factors influencing students' performance in a Brazilian dental school. Braz Dent J 2010;21:80-6.

26. Chattopadhyay A, Deol RS. Reasons for choice of dentistry as a career in Calcutta: a survey report. Indian J Dent Res 1990;2(1):140-4.

27. Al-Bitar ZB, Sonbol HN, Al-Omari IK. Reasons for choosing dentistry as a career by Arab dental students. Eur J Dent Educ 2008;12(2):89-98.

28. Coombs JA. An international comparison: American and Swedish dental students. J Dent Educ 1978;42(12):652-8.

29. Hawley NJ, Ditmyer MM, Sandoval VA. Predental students' attitudes toward and perceptions of the dental profession. J Dent Educ 2008;72(12):1458-64.
30. Butters JM, Winter PA. Professional motivation and career plan differences between African-American and Caucasian dental students: implications for improving workforce diversity. J Natl Med Assoc 2002;94:492-504.

31. Representação Brasil, Organização Pan-Americana da Saúde. Promoção da saúde. Reorientação das Práticas e Serviços de Saúde. Organização Pan-Americana da Saúde, 2008.

32. Stewart FM, Drummond JR, Carson L, Hoad Reddick G. A survey of dental school applicants' career intentions and the balance with family life. Br Dent J 2005;198:713-7.

33. The social causes of iniquities in health in Brazil. Rio de Janeiro, RJ: National Commission on the Social Determinants of Health, Editora Fiocruz, 2008.

34. Tarrío CM. Especialista ou clínico geral? Rev Assoc Paul Cir Dent 1995;49(1):8-17.

35. Lalloo R, Ayo-Yusuf OA, Yengopal V. Early-phase dental students' motivations and expectations concerning the study and profession of dentistry. S Afr Dent 2008;63(4):216-20.

36. Carvalho JAM, Garcia RA. The aging process in the Brazilian population: a demographic approach. Cad Saúde Pública/Rep Public Health 2003;19(3):725-33. 